\title{
THE NATURE AND GENETIC CONTROL OF GIBBERELLIN INSENSITIVITY IN DWARF WHEAT GRAIN
}

\author{
MICHAEL D. GALE and GERALDINE A. MARSHALL \\ Plant Breeding Institute, Cytogenetics Department, Maris Lane, \\ Trumpington, Cambridge CB2 2LQ
}

Received 1.xi.74

\begin{abstract}
SUMMARY
Eight dwarf and semi-dwarf varieties, covering a range of genetic sources of dwarfism, and four tall varieties of wheat were tested for their response to a range of GA concentrations by release of the enzyme $\alpha$-amylase. The two dwarfs, Minister Dwarf and Tom Thumb, were found to be insensitive compared with the remaining 10 varieties; among the latter, differences in minimum levels of sensitivity were found that were unrelated to height phenotype.

Transplant experiments, in which embryos of one genotype were grown on the endosperm of another, showed that the lack of response was a function only of the endosperm tissue and that GA release from the embryos of insensitive varieties during germination was similar to that of sensitive genotypes.

The close relationship between coleoptile length and endosperm GAinsensitivity indicated that this character was controlled by the Gai 3 locus previously located on chromosome $4 \mathrm{~A}$. In some crosses the character displayed a pattern of inheritance that would be expected in a triploid tissue for a single gene. However in crosses of varieties carrying Gai 3 with Norin 10-Brevor 14, which has a GA-sensitive endosperm, a more complex inheritance was found, indicating that Norin 10-Brevor 14 also carried a gene or genes which can increase GA-insensitivity.
\end{abstract}

\section{INTRODUCTION}

SOME dwarf wheats (Triticum aestivum, $2 n=6 x=42$ ) differ from tall wheats in their lack of response to applied gibberellin (GA). Allan, Vogel and Graddock (1959) first indicated an insensitive reaction to exogenous GA in dwarf and semi-dwarf varieties. Radley (1970), using semi-dwarf spring wheat cultivars derived from the Japenese variety Norin 10, showed that these genotypes had higher endogenous GA levels than control tall varieties. However, in these varieties, just as in most cereals, the aleurone layer surrounding the endosperm in the grain responds to exogenous GA or GA supplied by the embryo during germination by the production of the enzyme $\alpha$-amylase.

Recently Gale and Marshall (1973) showed that the two dwarfs, Minister Dwarf and Tom Thumb, were also GA-insensitive in terms of their shoot response and had high levels of GA in green tissues. These dwarfs, which are genetically distinct from those derived from Norin 10 (Chaudhry, 1973; Fick and Qualset, 1973), were also GA-insensitive in that the aleurone did not respond by the release of $\alpha$-amylase. Further, this lack of response was also associated with the presence of very low levels of the enzyme in mature grain.

Alpha-amylase content of the harvested crop is a most important consideration when assessing grain quality. In the bread-making process, an excess of the enzyme degrades the starch and causes the fermenting dough 
to become sticky and unmanageable. A low quality loaf with a sticky crumb structure is obtained from such dough (Farrand, 1964).

There are two reasons for the presence of excess $\alpha$-amylase in harvested grain. During maturation of the grain the level of active $\alpha$-amylase falls to a constant and relatively low value in the mature ripe seed, the resting level being a varietal characteristic. The second reason is applicable to most varieties. In the British climate, the summer rains around harvest time often cause the grain to "sprout" i.e. germinate in the ear before harvest. Although such germination does not often proceed beyond 1 or 2 days, the high levels of $\alpha$-amylase produced in sprouted grain are such that grain samples are unacceptable for milling with even a very limited degree of preharvest germination. The importance of this source of $\alpha$-amylase may be judged from the fact that in very wet years, such as 1968, the British baker may lose the use of more than half of the home crop.

The GA-insensitivity found in the grain of Minister Dwarf and Tom Thumb may prove useful since, on the one hand, the character is associated with very low levels in the ripe grain and, on the other, because even after 48 hours germination, as in sprouted grain, the enzyme levels are still lower than those found in some mature conventional wheats.

The possibility of exploiting this gene stimulated experiments to investigate the site of insensitivity in the dwarf grain and its genetic control.

\section{Materials and methods}

(i) Varieties

Twelve varieties (table 1 ), including a range of dwarf, semi-dwarf and tall genotypes were investigated.

TABLE 1

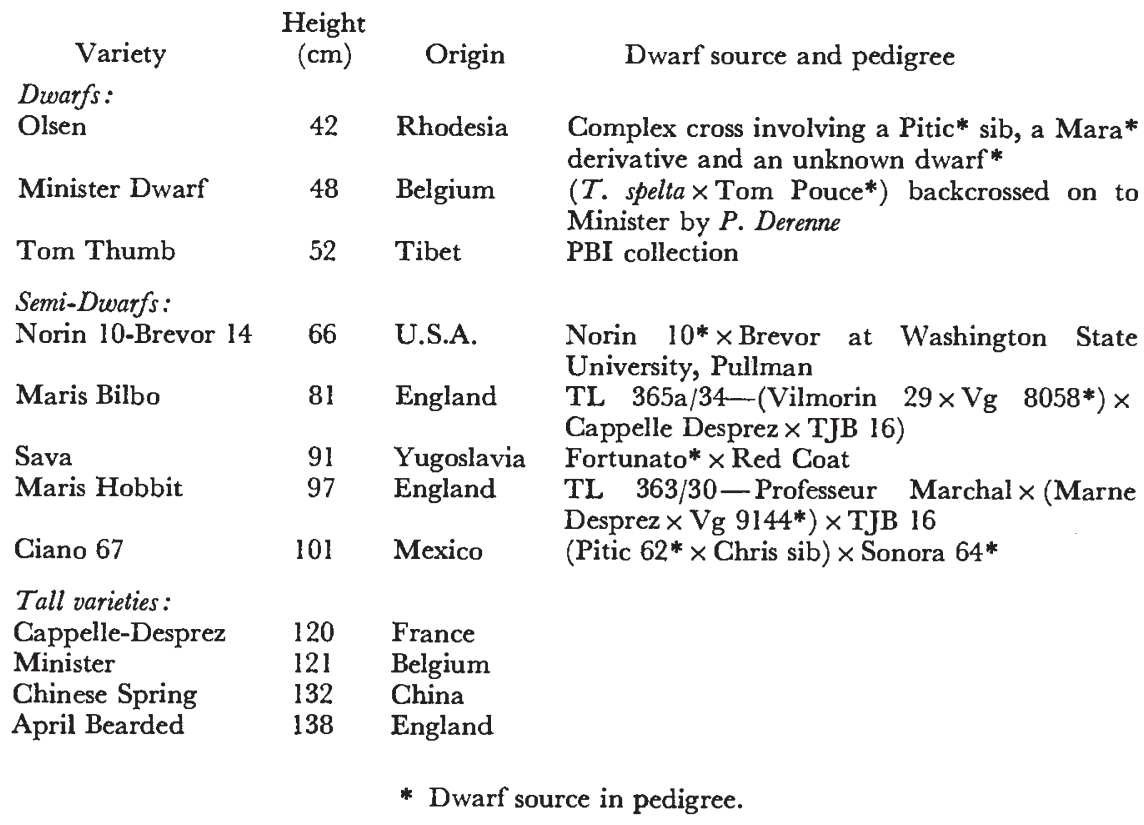


$F_{1}$ hybrids were obtained in the greenhouse in 1972, all crosses being made on to the taller parent. Backcrosses and $\mathrm{F}_{2}$ 's were obtained in 1973, and, unless otherwise stated, backcrosses were made on to the $F_{1}$, i.e. $B_{12.1}$ and $B_{12.2}$. Parental heights from the 1973 sowing are given in table 1 .

\section{(ii) Endosperm response}

Distal half-grains were cut from grain previously sterilised in $0 \cdot 1$ per cent $\mathrm{HgCl}_{2}$ for 2 minutes followed by 2 per cent $\mathrm{NaOCl}$ for 20 minutes and then rinsed thoroughly with sterile water. These were then incubated in sterile $25 \mathrm{ml}$ conical flasks containing $0.4 \mathrm{ml} 0.25 \mathrm{M}$ citrate buffer $(p \mathrm{H} 6.2), 0.4 \mathrm{ml}$ $0.1 \mathrm{M} \mathrm{CaCl}, 0.8 \mathrm{ml}$ sterile water and $0.4 \mathrm{ml}$ of $\mathrm{GA}_{3}$ solution. In the control vials water was used instead of GA solution. Streptomycin was added at a rate of 0.0025 per cent as an insurance against contamination. Incubation continued in a shaking water bath at $25^{\circ} \mathrm{C}$ for 72 hours after which the incubate and rinsings were collected and assayed for $\alpha$-amylase.

Initial experiments with grain from segregating generations were carried out using two replicate $2 \mathrm{~mm}$ endosperm segments. However, replicate error was found to be very small and later experiments employed only a single $3 \mathrm{~mm}$ distal half-grain so that greater numbers of progeny could be assayed.

Where required, the embryos in the proximal half-grains were grown on 1 per cent orchid agar for 6 days before coleoptile measurements were taken or seedlings were transplanted into pots.

\section{(iii) Transplant technique}

Sterilised grain was soaked in sterile water for 20 hours before embryos were dissected out, free from starch and seed coat. These were stored for short periods in sterile water. $3 \mathrm{~mm}$ endosperm slices were cut from whole grain, sterilised with $\mathrm{NaOGl}$ and then allowed to imbibe sterile water for 20 hours, to match the embryos. Embryos were placed on endosperms mounted in agar containing 0.0025 per cent streptomycin in sterile petri dishes. Germination levels were observed after 48 hours at $25^{\circ} \mathrm{C}$. Both transplant halves were then homogenised in 2 per cent $\mathrm{NaCl}, 0.02$ per cent calcium acetate solution and the supernatant assayed for $\alpha$-amylase after centrifugation at $1000 \mathrm{~g}$.

\section{(iv) Alpha-amylase assay}

Alpha-amylase was assayed using an auto-analyser system similar to that described by Smith (1972). The system was calibrated in U using fungal $\alpha$-amylase (Sigma Chemical Co.) of known activity as measured by the Phadebas (Pharmacia AB, Uppsala, Sweden) amylase test. The relationship of activity to optical density, with the sample peak $\left(\mathrm{OD}_{s}\right)$ range $0 \cdot 1-0 \cdot 6$ and with a baseline optical density $\left(O D_{B}\right)$ of $0 \cdot 7 \pm 0.05$, was found to be

$$
\log U / L=\text { Probit }\left(\mathrm{OD}_{B}-\mathrm{OD}_{s} / \mathrm{OD}_{B}\right)-K_{1} / K_{2}
$$

$K_{1}$ and $K_{2}$ are regression constants characteristic of the auto-analyser and the substrate, in this case $\beta$-limit dextrin (Rank Hovis MacDougal, Southampton) at $0.6 \mathrm{~g}$ per $100 \mathrm{ml}$ sterile water. Errors are given as 5 per cent least significant differences $\left(\mathrm{LSD}_{5 \%}\right)$ and are applicable only to the $\log U$ means. 


\section{RESULTS}

(i) Varietal differences in endosperm response

Previous results (Gale and Marshall, 1973) established a difference in the sensitivity of the germinating grain to applied GA between the dwarfs Minister Dwarf and Tom Thumb, and other varieties including a semi-dwarf, Norin 10-Brevor 14. In order to extend these observations, the response of the endosperm to a range of GA concentrations was measured for the 12 varieties listed in table 1 . The response of distal half-grains, rather than that of germinating whole grains was preferred since the results would not be confounded by possible differences in the additional endogenous GA supplied by a developing embryo.

TABLE 2

Release of $\alpha$-amylase in response to $G A_{3}$

\begin{tabular}{|c|c|c|c|c|}
\hline \multirow[b]{2}{*}{ Variety } & \multicolumn{4}{|c|}{$\mathrm{GA}_{3}$ concentration } \\
\hline & Control & $10^{-9} \mathrm{M}$ & $10^{-7} \mathrm{M}$ & $10^{-5} \mathrm{M}$ \\
\hline $\begin{array}{l}\text { Dwarfs: } \\
\text { Minister Dwarf } \\
\text { Tom Thumb } \\
\text { Olsen }\end{array}$ & $\begin{array}{l}0 \cdot 50 \\
0 \cdot 73 \\
0 \cdot 88\end{array}$ & $\begin{array}{l}0 \cdot 70 \\
0 \cdot 63 \\
1 \cdot 90\end{array}$ & $\begin{array}{l}0 \cdot 73 \\
1 \cdot 08 \\
4 \cdot 87\end{array}$ & $\begin{array}{l}2 \cdot 32 \\
1 \cdot 00 \\
4 \cdot 92\end{array}$ \\
\hline 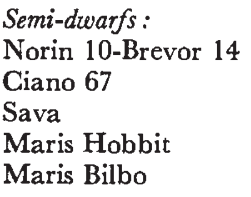 & $\begin{array}{l}0.51 \\
0.52 \\
0.68 \\
0.54 \\
0.44\end{array}$ & $\begin{array}{l}0 \cdot 83 \\
1 \cdot 05 \\
0 \cdot 43 \\
1 \cdot 64 \\
0 \cdot 70\end{array}$ & $\begin{array}{l}0 \cdot 74 \\
4 \cdot 92 \\
4 \cdot 34 \\
4 \cdot 70 \\
4 \cdot 30\end{array}$ & $\begin{array}{l}4 \cdot 62 \\
4 \cdot 95 \\
4 \cdot 55 \\
4 \cdot 82 \\
4 \cdot 40\end{array}$ \\
\hline $\begin{array}{l}\text { Tall varieties: } \\
\text { Cappelle-Desprez } \\
\text { Minister } \\
\text { Chinese Spring } \\
\text { April Bearded }\end{array}$ & $\begin{array}{l}0 \cdot 38 \\
1 \cdot 60 \\
0 \cdot 87 \\
0 \cdot 68\end{array}$ & $\begin{array}{l}0.49 \\
3 \cdot 38 \\
0 \cdot 90 \\
1.79\end{array}$ & $\begin{array}{l}4 \cdot 71 \\
4 \cdot 55 \\
4 \cdot 74 \\
4 \cdot 68\end{array}$ & $\begin{array}{l}4 \cdot 75 \\
4 \cdot 64 \\
4 \cdot 85 \\
4 \cdot 52\end{array}$ \\
\hline
\end{tabular}

Note: Enzyme levels assayed after 72 hours and recorded as $\log U+1 \mathrm{~g}$. Values are means of three replicates of 5 grains. $\mathrm{LSD}_{5 \%}=0 \cdot 67$.

Table 2 shows the amounts of $\alpha$-amylase released by endosperms at 72 hours. The GA concentrations cover the rising portion of the doseresponse curve for this system for which the optimum level had previously been ascertained at about $10^{-4} \mathrm{M} \mathrm{GA}_{3}$.

Clearly Minister Dwarf and Tom Thumb are less responsive than the other 10 genotypes. However, differences of a more quantitative nature may be found among the varieties with GA-sensitive endosperms. The minimum GA concentrations at which a definite response is observed varies from greater than $10^{-7} \mathrm{M}$ for Norin 10 -Brevor 14 to less than $10^{-9} \mathrm{M}$ for Minister. These differences appear to be unrelated to plant height, GAsensitivity of shoot tissues or winter-spring habit.

Norin 10-Brevor 14 carries genes which make the shoot GA-insensitive. However, if the lack of response in the endosperm of this variety is due to partial penetrance of these genes then an explanation must be sought for the comparative responsiveness of Olsen, Ciano 67, Maris Hobbit and Maris Bilbo. These varieties all have the GA-insensitive shoot phenotype derived 
from Norin 10. It is possible that the effect in Norin 10-Brevor 14 is due to the interaction of two or more of these genes which are present only singly in the other Norin 10 based varieties examined.

The significance of the extreme sensitivity found in Minister, Olsen, April Bearded and Maris Hobbit is not understood. Certainly, in greenhouse grown material, high $\alpha$-amylase levels at low GA concentrations do not reflect the presence of sprouted grain.

The two unresponsive genotypes, Minister Dwarf and Tom Thumb, differ from the other varieties in that they carry a single major gene controlling GA-insensitivity in aerial tissues on chromosome 4A (Gale, Law, Marshall and Worland, 1975). Evidence presented below indicates that the same locus, Gai 3, controls insensitivity of the aleurone layer. However, the " leaky" response of Minister Dwarf at high GA concentrations, compared with the almost complete insensitivity of Tom Thumb, is consistently found among segregants of hybrids involving Tom Thumb and Minister Dwarf with a wide range of other varieties. Therefore it is possible that these two dwarfs carry different alleles at the Gai 3 locus.

\section{(ii) Inter-varietal transplants}

Insensitivity to GA in aerial plant parts has been found to be associated with high endogenous GA levels by Radley (1970) and Gale and Marshall (1973). These authors have assumed that this is a causal relationship stemming from non-utilisation and consequent build-up in the tissues of GA produced by a normal synthetic pathway. The wheat grain carrying the Gai 3 gene provides a system whereby this assumption may be tested. The site of GA release, the embryo, may be manipulated independently of the target tissue, the aleurone layer surrounding the endosperm.

The four reciprocal transplants of Minister Dwarf and Minister embryos on to each endosperm are shown after 48 hours growth in plate I. Relative growth rates demonstrate a difference between the endosperms rather than between the embryos. Both Minister and Minister Dwarf embryos are capable of stimulating mobilisation in the Minister endosperm indicating that the embryo of the insensitive Minister Dwarf genotype is effective in release of active GA.

These observations may be quantified in terms of the induced enzyme $\alpha$-amylase found in the transplant tissues at 48 hours, these results are shown in table 3. The response of the Minister ( $\mathrm{gai} 3$ ) endosperm indicates identical stimuli from both the Gai 3 and gai 3 embryos. The lower levels of enzyme

l'ABLE 3

Intervarietal transplants- $\alpha$-amylase

$\begin{array}{ccc}\begin{array}{c}\text { Transplant } \\ \text { embryo/endosperm }\end{array} & \text { Embryo } & \text { Endosperm } \\ \text { MD/MD } & 1 \cdot 89 & 1 \cdot 45 \\ \text { MD/MIN } & 1 \cdot 83 & 3.24 \\ \text { MIN/MD } & 2 \cdot 15 & 1 \cdot 65 \\ \text { MIN/MIN } & 2 \cdot 11 & 3 \cdot 19\end{array}$

Notes: Enzyme extracted and assayed after 48 hours at $25^{\circ} \mathrm{C}$. Enzvme values are given in $\log U$ and are means of five replicates. $\mathrm{LSD}_{5 \%}=0 \cdot 273 . \mathrm{MD}=$ Minister Dwarf, MIN $=$ Minister. 
found in the Gai 3 embryos probably also reflects an insensitive response of the aleurone that surrounds at least part of the scutellar regions. Similar results have been obtained in similar transplant series in which the two transplant halves have been separated by a dialysis membrane. Thus it is clear that only small molecules pass between the embryo and endosperm halves and the possibility of transfer of enzymes from endosperm to embryo is excluded.

\section{(iii) The inheritance of endosperm insensitivity}

Previously it has been shown that GA-insensitivity of aerial plant parts is controlled by a single dominant gene (Gale et al., 1975). The two characters GA-insensitivity and coleoptile length remained completely associated in segregating families from a cross between a GA-sensitive parent with a long coleoptile, and Minister Dwarf which is GA-insensitive and has a short coleoptile. Thus, in the absence of any apparent recombination it was assumed that the two characters were under the pleiotropic control of the Gai 3 locus located on chromosome 4A.

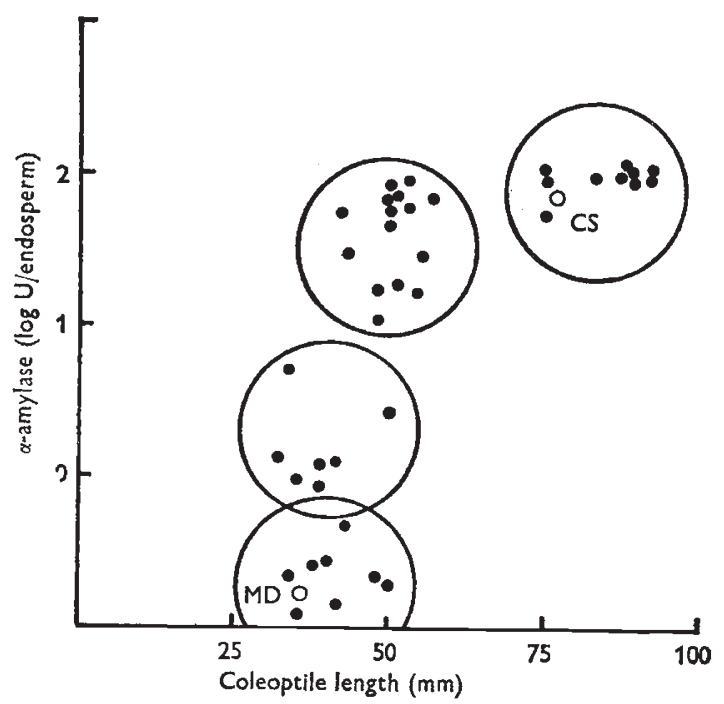

Fig. 1.-Coleoptile lengths and GA-induced $\alpha$-amylase release among $F_{2}$ progeny from a cross of Chinese Spring $\times$ Minister Dwarf $\mathbf{F}_{2}$. Note: Untreated coleoptiles were measured after 6 days growth at $25^{\circ} \mathrm{C}$ in the dark. $\mathrm{O}=$ Parental means.

The results shown in fig. 1 indicate complete association between endosperm insensitivity and coleoptile length in an $\mathrm{F}_{2}$ family of Chinese Spring (CS) $\times$ Minister Dwarf. The lack of individuals with long coleoptiles displaying low $\alpha$-amylase after GA treatment strongly suggests that Gai 3 also controls the response of the endosperm.

However fig. 1 clearly shows that the inheritance of the two characters is different. Two coleoptile phenotypes in the proportion of 3 short: 1 long indicate a single gene with almost complete dominance for the Minister Dwarf phenotype. The endosperm phenotypes, on the other hand, fall into two approximately equal groups of highly responsive ( $>1 U \alpha$-amylase) individuals and those with low response ( $<1 U \alpha$-amylase). The relation 

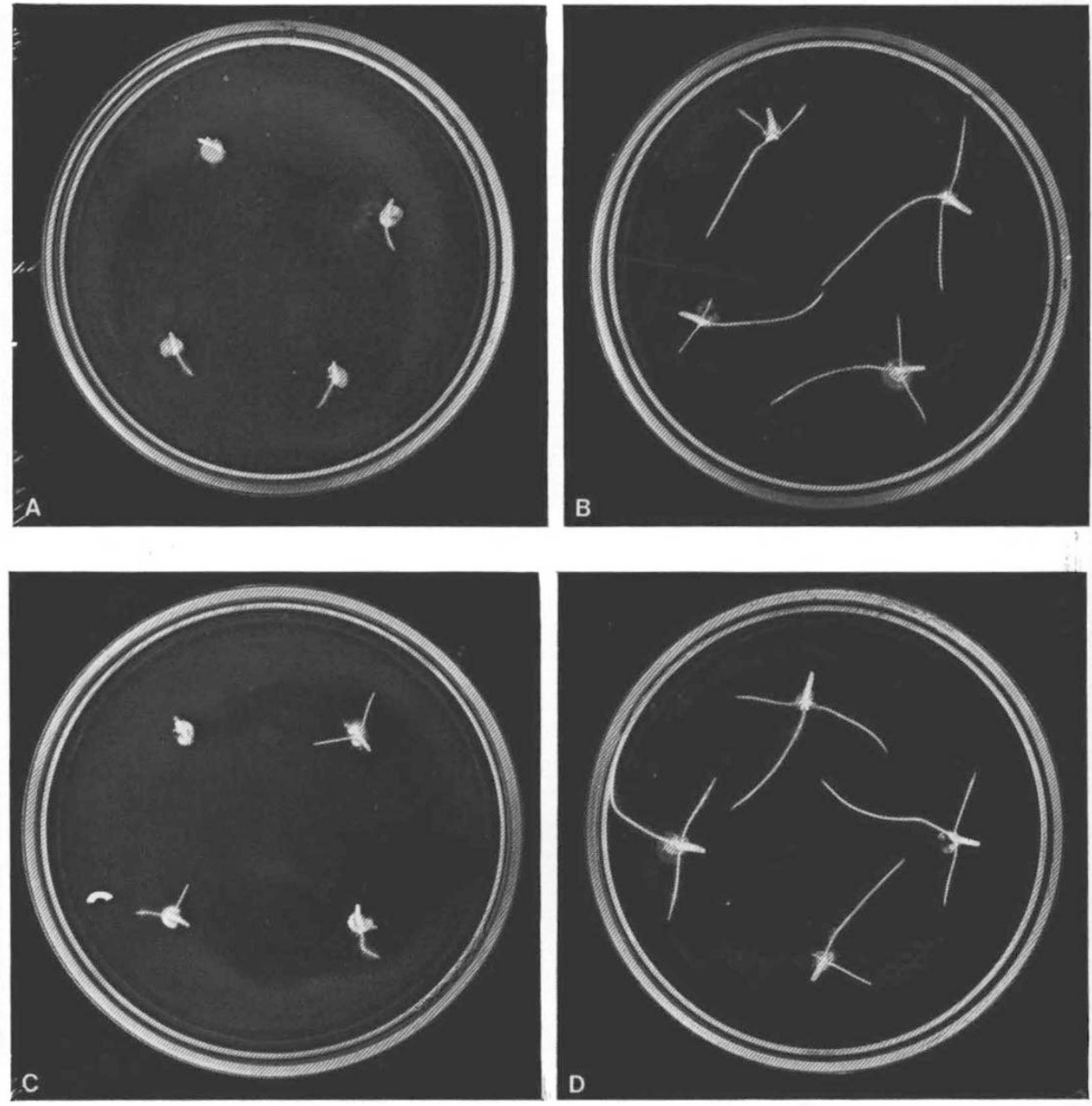

Plate I

Intervarietal transplants between Minister Dwarf (MD) and Minister (MIN)growth at 48 hours.

$\begin{array}{lll} & \text { Embryo } & \text { Endosperm } \\ a & \text { MD } & \text { MD } \\ b & \text { MD } & \text { MIN } \\ c & \text { MIN } & \text { MD } \\ d & \text { MIN } & \text { MIN }\end{array}$


of the two characters suggests three, and possibly four, distinct phenotypes, as indicated by the circles in fig. 1. This may be explained by the pleiotropic action of a gene in both diploid coleoptile and triploid endosperm tissues. Table 4 shows the genetic consequences in the $F_{2}$ and backcross families of fusion of one of the two identical male gametic nuclei with the female egg nucleus to give rise to the embryo, and the other with the two polar nuclei to form the endosperm. The egg and polar nuclei have arisen mitotically from a single cell and are consequently genetically identical. In the $\mathrm{F}_{2}$, the heterozygotes Gai 3 gai 3 which are identical in diploid tissues become distinct as triploids, i.e. Gai 3 (Gai 3 gai 3) and gai 3 (gai 3 Gai 3). The differing dosage dominance relationships for the Gai 3 locus in the coleoptile and endosperm separate all four genotypes phenotypically.

TABLE 4

Segregation at a single locus for a gene with pleiotropic effects on the phenotype of both triploid and diploid tissues

\begin{tabular}{|c|c|c|c|}
\hline \multicolumn{4}{|c|}{$\mathrm{P}_{1}($ gai 3 gai 3$) \times \mathrm{P}_{2}($ Gai 3 Gai 3$), \mathrm{F}_{1}($ gai 3 Gai 3$)$} \\
\hline $\begin{array}{c}\text { Gametes } \\
\text { o }\end{array}$ & gai 3 & Gai 3 & Family \\
\hline $\begin{array}{l}\text { gai } 3 \text { gai } 3 \\
\text { Gai } 3 \text { Gai } 3\end{array}$ & $\begin{array}{r}\text { gai } 3 \text { (gai } 3 \text { gai 3) } \\
\text { Gai } 3(\text { Gai } 3 \text { gai } 3)\end{array}$ & $\begin{array}{r}\text { gai } 3(\text { gai } 3 \text { Gai } 3) \\
\text { Gai } 3(\text { Gai } 3 \text { Gai } 3)\end{array}$ & $\begin{array}{l}\mathrm{B}_{1.12} \\
\mathrm{~B}_{2 \cdot 12} \\
\mathrm{~F}\end{array}$ \\
\hline
\end{tabular}

Note: Diploid genotype shown in brackets.

Clearly, such a situation should produce four different $1: 1$ segregations in all the possible reciprocal backcrosses. Fig. 2 shows the results obtained for four such families from the cross Minister $\times$ Minister Dwarf. In this cross the $\alpha$-amylase phenotype after GA treatment is distinct for all four gene doses, from $0-3$, in the triploid genome. The differences in the mean coleoptile lengths of, for example, the gai 3 ( $\mathrm{gai} 3 \mathrm{Gai} 3$ ) genotypes, in the $\mathbf{B}_{\mathbf{1 2 . 2}}$ and $\mathbf{B}_{\mathbf{1 . 1 2}}$ families, is indicative of other minor gene differences such as those found by Gale et al., 1975 in the control of this character between the two varieties. The overriding effect of the Gai 3 locus can, however be distinguished clearly.

Tom Thumb also carries an allele conferring GA insensitivity at the Gai 3 locus. The $\mathbf{F}_{\mathbf{2}}, \mathbf{B}_{\mathbf{1 2 . 1}}$ and $\mathbf{B}_{\mathbf{1 2 . 2}}$ progeny from the crosses CappelleDesprez $\times$ Tom Thumb and Norin 10 -Brevor $14 \times$ Tom Thumb are shown in figs. 3 and 4 . Where only the induced $\alpha$-amylase levels are available, the data are necessarily more difficult to interpret than in families where the genotype may be determined by its combined effect upon coleoptile length and endosperm response. However, in crosses involving other dwarfs such as Norin 10-Brevor 14 the effect of Gai 3 on coleoptile length is confounded by the similar effect of the height reducing genes derived from Norin 10 .

The data in fig. 3 suggests a genetic situation similar to that found in the Ghinese Spring $\times$ Minister Dwarf $\mathrm{F}_{2}$ shown in fig. 1. The GA-induced $\alpha$-amylase levels may be grouped into discrete low and high classes in all three segregating generations. However, whereas these classes are unimodal in the backcrosses, there is a suggestion of bimodality in the $\mathrm{F}_{2}$ indicating the presence of the four phenotypes, $\mathrm{L}, \mathrm{L}^{+}, \mathrm{H}^{-}$and $\mathrm{H}$. If the absolute values for individuals within classes vary in a similar way then the within class variability will decrease up the logarithmic $\alpha$-amylase index. However the 
L class, which comprises all individuals with barely detectable levels of enzyme release, will have a small variance. Thus the subjective assignation of individuals to the intermediate classes is more arguable than to the extreme groups. Nevertheless, using only the discrete classes, the data are not inconsistent with a hypothesis of monogenic inheritance as shown in table 4. $\mathrm{B}_{12.1}$ is in agreement with $1 \mathrm{~L}^{+}: 1 \mathrm{H}\left(\chi^{2}=1 \cdot 8\right), \mathrm{B}_{12.2}$ with IL : $1 \mathrm{H}^{-}\left(\chi^{2}=1 \cdot 3\right)$ and the $\mathrm{F}_{2}$ with $1\left(\mathrm{~L}+\mathrm{L}^{+}\right): 1\left(\mathrm{H}^{-}+\mathrm{H}\right)\left(\chi^{2}=0.6\right)$.

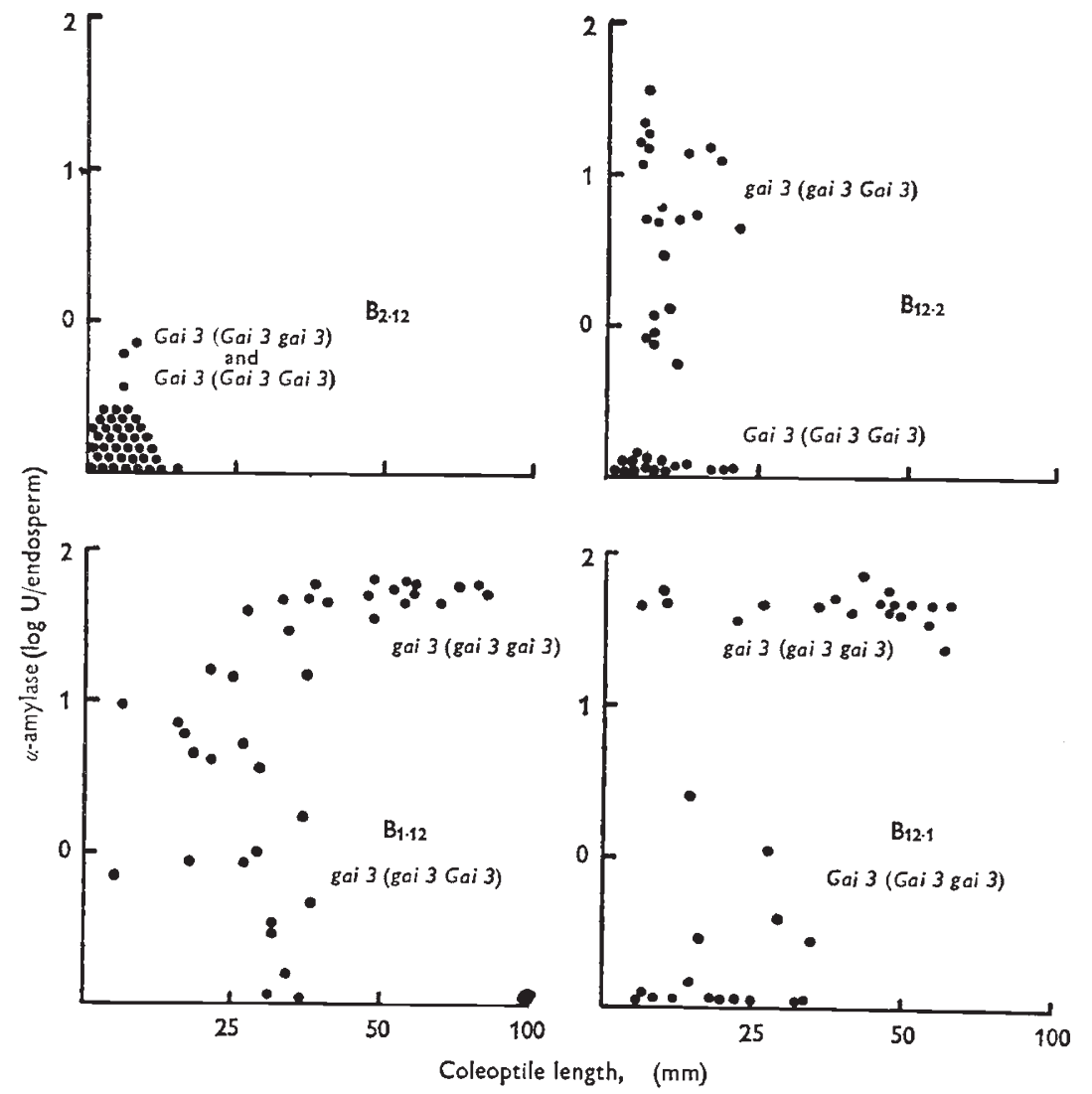

Frg. 2.-Coleoptile lengths and GA-induced $\alpha$-amylase release in the four reciprocal backcrosses of Minister $\times$ Minister Dwarf.

The data for crosses involving Norin 10-Brevor 14 in fig. 4 differ from the relatively simple situation described above. First, the $F_{2}$ and $B_{12.1}$ families contain individuals more responsive than the Norin 10-Brevor 14 parent. Secondly, there is an excess of very insensitive individuals in both the $F_{2}$ and $B_{12.2}$ families, over that expected under the monogenic control situation. And thirdly, there are some individuals with very low $\alpha$-amylase in $B_{12.1}$ where none are found in, for example, the same family in the CappelleDesprez $\times$ Tom Thumb cross in fig. 3 . These departures from the expected segregations for a monogenic situation indicate the presence of an additional gene or genes for endosperm insensitivity different from Gai 3 and contributed 
by Norin 10-Brevor 14. The data have been grouped into five classes which correspond to the four phenotypes found in the Cappelle-Desprez $\times$ Tom Thumb crosses plus an intermediate group I. An example of a possible model based on the segregation of two genes- $A$, corresponding to Gai 3 from Tom Thumb, and $B$, a gene of lesser effect carried by Norin 10-Brevor 14-
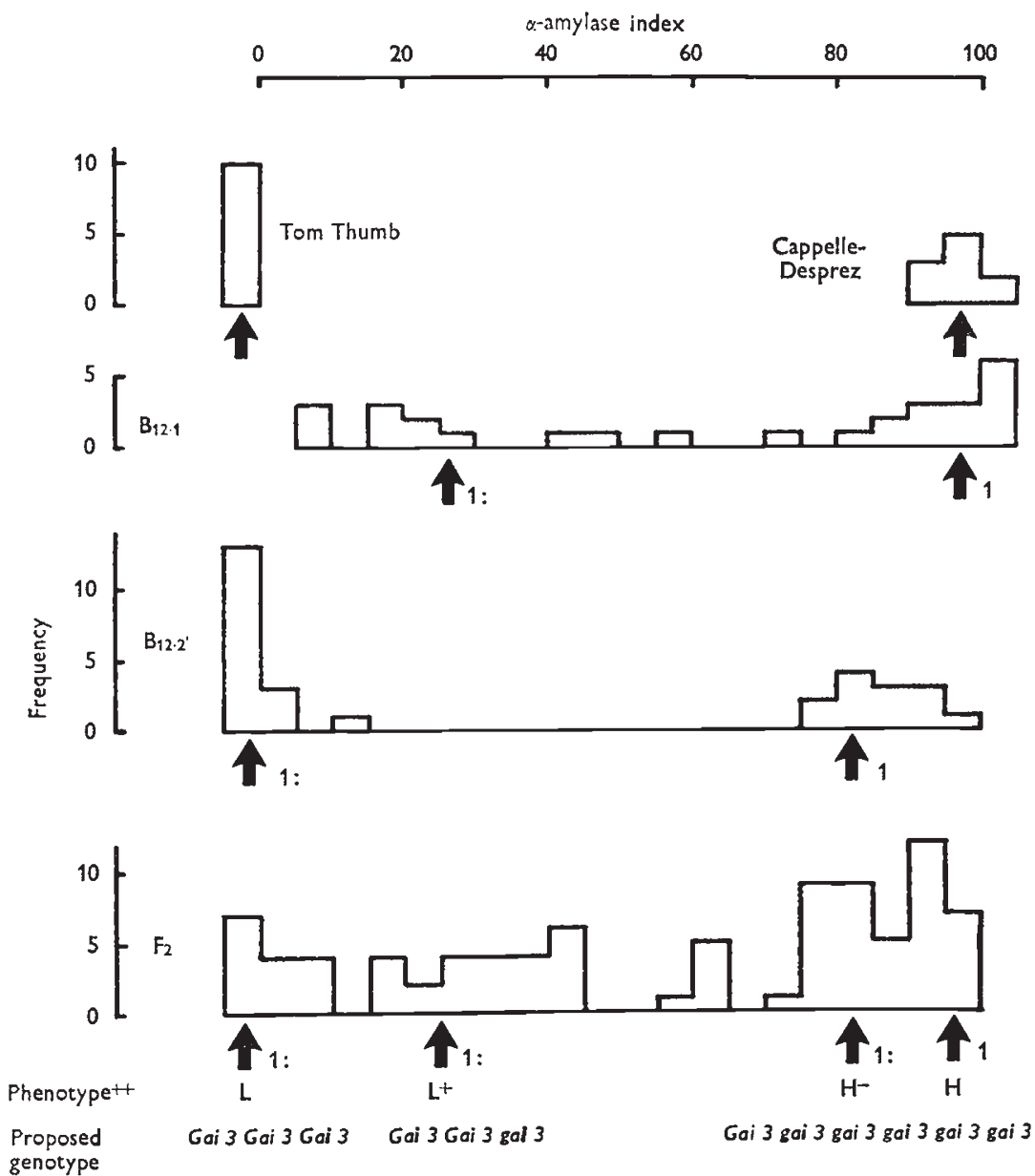

FIG. 3.-GA-induced $\alpha$-amylase release in backcross and $F_{2}$ progeny of Cappelle-Desprez $\left(\mathrm{P}_{1}\right) \times$ Tom Thumb $\left(\mathrm{P}_{2}\right)$. Note: $\dagger=\alpha$-amylase index is a logarithmic scale relative to Tom Thumb $(0)$ and Chinese Spring (100) included in all assays. $\dagger+=$ the modes and expected frequencies for the phenotypic classes corresponding to the triploid genotypes are shown by the arrows.

is shown on fig. 4. A good fit between the observed and expected segregations where reasonable distinctions may be made, is obtained on the basis of this model. In $\mathrm{B}_{12.1}$ three classes $\left(\mathrm{L}+\mathrm{L}^{+}\right), \mathrm{H}^{-}$and $\mathrm{H}$ may be discerned that fit a $2: 1: 1$ segregation $\left(\chi^{2}=1.06\right)$ and in $B_{12.2}$ two classes corresponding to $\left(\mathrm{L}+\mathrm{L}^{+}\right)$and I fit the $3: 1$ expectation, $\chi^{2}=0 \cdot 04$. Of the five genotypic classes in the $\mathrm{F}_{2}$ reasonable distinction may be made between four phenotypic groups $\left(\mathrm{L}+\mathrm{L}^{+}\right), \mathrm{I}, \mathrm{H}^{-}$and $\mathrm{H}$ these give a $\chi^{2}=1 \cdot 19$, for a fit to 
$10: 2: 2: 2$. The groupings are of an arbitrary nature and represent one of the simplest of many models that might accommodate the data. It is therefore difficult to provide a test of whether the two genes interact or behave in an additive fashion. Likewise it cannot be stated unequivocally that only a single additional gene is contributed by Norin 10-Brevor 14 .

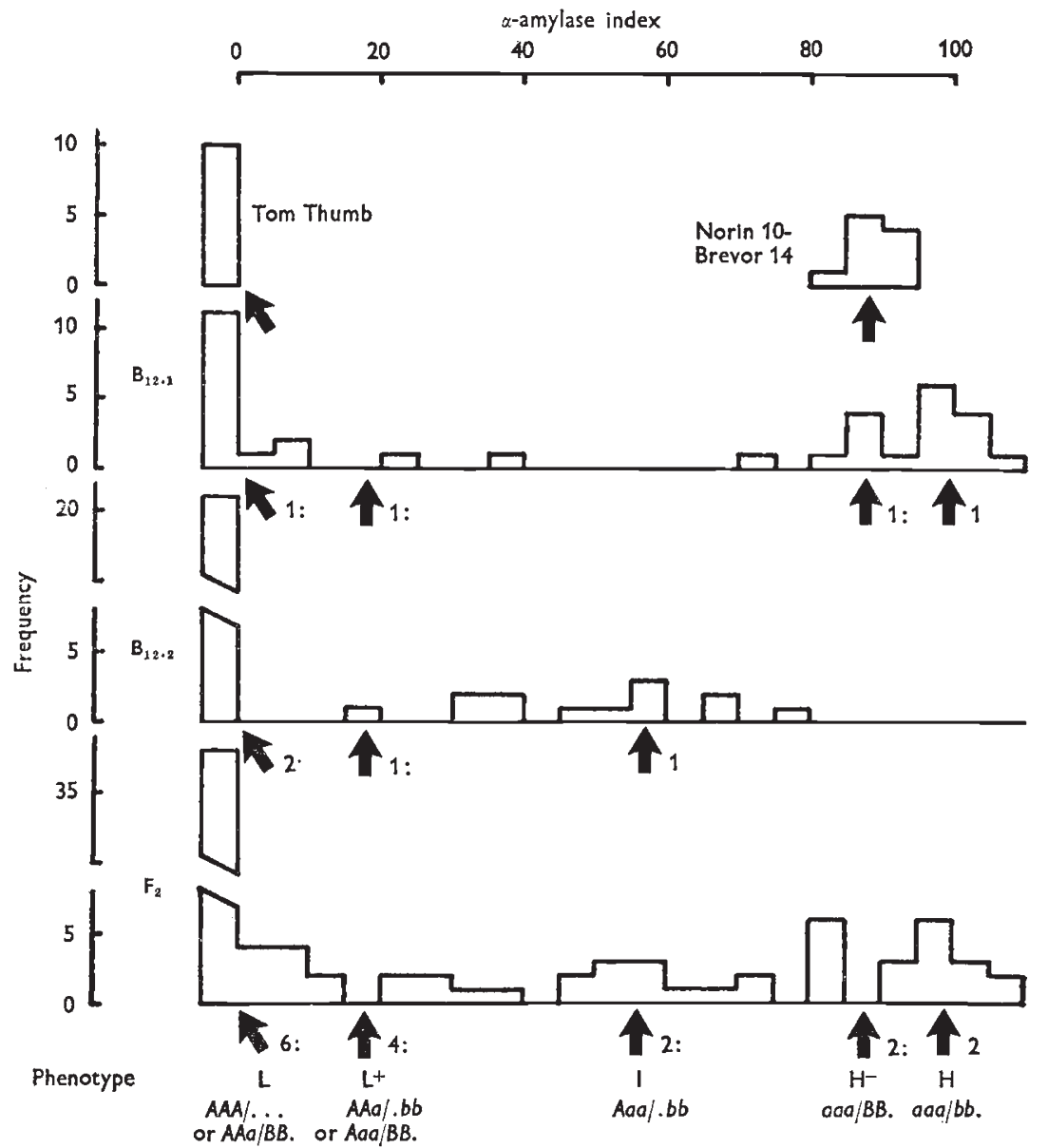

FiG. 4.-GA-induced $\alpha$-amylase release in backcross and $F_{2}$ progeny of Norin 10-Brevor 14 $\left(\mathbf{P}_{1}\right) \times$ Tom Thumb $\left(\mathbf{P}_{2}\right)$. Note: $\dagger$ and $\dagger \dagger$, see fig. 3. Modes and expected frequencies assume digenic triploid inheritance. $\dagger \uparrow \uparrow, \mathrm{A}=$ Gai $3, \mathrm{~B}=$ unlocated gene in NB14, either allele.

\section{Conclusions}

Norin 10 dwarf and semi-dwarf derivatives carry at least one GAinsensitivity gene that operates in aerial plant tissues. However GAinsensitivity from this genetic source does not operate fully in the aleurone of germinating grains. Minister Dwarf and Tom Thumb, carrying a Gai 3 allele on chromosome 4A, are GA-insensitive in both types of reactions.

The insensitive response is associated with high endogenous levels of GA in seedlings, mature stems and leaf material, while, in the germinating grain, 
the lack of response is associated with normal GA production. Therefore the build-up of hormone would seem to be a consequence of non-utilisation and it is likely that the Gai 3 allele acts upon the turnover of gibberellin in the plant. Also, the allele is an active gene rather than a null mutation of its wildtype allele, since nullisomic genotypes lacking chromosome $4 \mathrm{~A}$ behave as sensitive gai 3 gai 3 plants. Furthermore this activity may be observed as a dosage series in triploid endosperm tissue, where the degree of response is dependent on the number of alleles present. Thus it is possible that the gene could act via the production of a GA antagonist at rates proportional to the number of doses of the gene. Also since genotypes homozygous for Gai 3 are insensitive to very high concentrations of exogenous GA, it would seem that the antagonist must act upon the "active sites" of gibberellin action of which there must be a limited number, rather than upon the gibberellin molecule itself.

The Gai 3 gene has obvious uses for the wheat breeder in that it will provide low levels of the unwanted enzyme in flour from the ripe crop and even from sprouted grain. It is also likely that other genes exist, such as those responsible for the modified response of Norin 10-Brevor 14 both as a pure line and in the crosses with Tom Thumb, that may provide a degree of improvement in $\alpha$-amylase content and apparent sprouting resistance.

The value of these genes will, however, depend on the extent and nature of their pleiotropic effects on other characters, especially upon other facets of grain quality. The aleurone cells are the site of synthesis of many enzymes both during grain development and germination. Recent experiments have shown that the release of at least two other GA-induced enzymes, acid phosphatase and peroxidase, is restricted in genotypes carrying Gai 3 and that Gai 3 aleurones take on the insensitive character well before final grain ripening. Consequently further work must be done to evaluate the hazards of exploiting such a basic change in endosperm metabolism.

Acknowledgment.-We would like to thank Mrs Jean Chambers for her technical assistance.

\section{REFERENCES}

ALlAN, R. E., VOGEL, O. A., AND CRADDOCK, J. C. JR. 1959. Comparative response to gibberellic acid of dwarf, semi-dwarf and standard short and tall winter wheat varieties. Agronomy Journal, 51, 737-740.

CHAUDHry, A. s. 1973. A genetic and cytogenetic study of height in wheat. Ph.D. thesis, Cambridge University.

FARRAND, E. A. 1964. Flour properties in relation to the modern bread processes in the United Kingdom, with special reference to $\alpha$-amylase and starch damage. Cereal Chemistry, 41, 98-111.

FICK, G. N., AND QUALSET, c. o. 1973. Genes for dwarfness in wheat, Triticum aestivum L. Genetics, 75, 531-539.

GALE, M. D., LAW, C. N., MaRshall, G. A., AND WORLAND, A. J. 1975. The genetic control of gibberellic acid insensitivity and coleoptile length in a "Dwarf" wheat. Heredity, 34, 393-399.

Gale, M. D., AND Marshall, G. A. 1973. Dwarf wheats and gibberellins. Proc. IVth Int. Wheat Genetics Symposium 1973, 513-519.

RADley, M. 1970. Comparison of endogenous gibberellins and response to applied gibberellin of some dwarf and tall wheat cultivars. Planta, 92, 292-300.

SMITH, D. B. 1972. An automated method for the determination of $\alpha$-amylase activities in cereal extracts. In Automation in Analytical Chemistry-Technicon International Symposium, 1970.

$35 / 1-E$ 